\title{
The Impact of the Covid-19 Pandemic on the Growth of Micro, Small, and Medium Enterprises (MSMEs)
}

\author{
Nanda Ameliany, S.Pd, M.Si ${ }^{1 *}$, Maisyura, SE, M.S.M ${ }^{1}$, Lisa Iryani, S.Sos, M.A.P ${ }^{l}$ \\ ${ }^{1}$ Administrasi Bisnis, Universitas Malikussaleh \\ *Corresponding author: nanda.ameliany@unimal.ac.id
}

\begin{abstract}
Covid-19 is an infectious disease caused by the newly discovered coronavirus. This virus began to become epidemic in Wuhan, China since December 2019. With a very fast spread, Covid-19 has become a pandemic that occurs throughout the world. Covid-19 has had a huge impact on all aspects of life, and all areas in a country. Indonesia is one of the countries affected by Covid-19. The most impact felt by a country is in the economic field. Obstruction of economic activity then affects state income. The impact of Covid-19 apart from affecting big business income, also affects micro businesses that are widely spread in Indonesia. Micro, Small and Medium Enterprises (MSMEs) in Indonesia have had a considerable influence, so that during this pandemic period many negative impacts were felt. This pandemic caused a decline in performance on the demand side, namely consumption and purchasing power, which then disrupted the production and trade processes. In addition, this situation creates new problems for termination of employment and the threat of default on credit payments. This significant reduction in the workforce has resulted in a lot of unemployment. The government has made various efforts to save Micro, Small and Medium Enterprises (MSMEs) from the impact of the COVID-19 pandemic. The purpose of this study is to map government policies in the MSME policy and map the short-term and long-term strategies needed to complement these policies. This research uses qualitative methods. The study uses secondary data from various literatures such as books, articles, and homepages to access data and information related to policies to save MSMEs from the impact of the COVID-19 pandemic. The analysis technique was carried out by descriptive analysis. Based on research, it is known that the policy of saving MSMEs from the impact of the COVID-19 pandemic needs to be supported by a short-term strategy and a long-term strategy to maintain the sustainability of MSMEs as one of the actors of the Indonesian economy.
\end{abstract}

Keywords: The growth of MSMEs during the pandemic of covid 19

\section{INTRODUCTION}

Micro, Small and Medium Enterprises (MSMEs) are productive businesses owned by individuals and business entities that have met the criteria of being a micro business, for example a culinary business. In the last ten years, the development of MSMEs in Indonesia has reached 99.9 percent of the total business units in Indonesia. The number of MSMEs spread across Indonesia is 62.9 million units covering trade, agriculture, livestock, forestry, fisheries, mining, processing, buildings, communications, hotels, restaurants and services. The development of MSMEs in Indonesia cannot be separated from the factors that drive the growth of MSMEs in Indonesia, including the use of technology, information and communication facilities, the ease of borrowing business capital, and the reduction in the final $\mathrm{PPH}$ rate. 
Even so, the growth is still considered slow because several factors are considered not very effective, one of which is the business taxation sector. In the midst of the development of MSMEs that have not been too good at the beginning of 2020, MSMEs in Indonesia were again tested with the emergence of the Covid-19 outbreak in Indonesian society. The Covid-19 outbreak began to emerge in Wuhan City, Hubei Province, China in December 2019, and was designated a pandemic by the world health organization WHO. More than 620,000 cases of Covid-19 have been reported in more than 190 countries, resulting in more than 28,800 deaths and 137,000 of them recovered [7].

Like in Italy, the spread of the corona virus is very massive due to the people still doing activities outside the home as usual. Taking a lesson from the Italian case, Social Distancing should be carried out to prevent the spread of the Covid-19 or also known as Lockdown (regional quarantine). Thus, in Indonesia as well, the government has tried these efforts which have a direct impact on the drastic decline of the MSME economy, because every citizen, even school students, is closed to stay at home. As a result, UMKM companies are hampered in sales and production.

The spread of the Covid-19 virus has an impact on MSME players in Indonesia. One of them is Amin S Sutimin, who owns Aneka Jaya Glass decorative lantern business in Jakarta. Amin admitted that the transactions he got had suddenly decreased since January 2020. "I think it's because of the corona virus, I don't know why suddenly our transactions since January fell by 20 percent," he said. Amin said that in a month the turnover usually reaches 100 million rupiahs. The turnover was obtained because he exported his products to the United States and Australia. Not only that, the tourism and trade sectors have also experienced a drastic decline, especially for street vendors who are no longer able to trade due to the imposition of social restrictions, as well as online transportation.

However, there are several factors that make MSMEs able to survive amid the Covid-19 outbreak. First, generally MSMEs produce consumer goods and services that are close to people's needs. The drastic decline in people's income did not have much effect on the demand for goods and services produced. MSMEs can even move and absorb labor even though the numbers are limited in the Covid-19 situation. Second, MSME business actors generally utilize local resources, whether human resources, capital, raw materials, or equipment. This means that most MSME needs do not rely on imported goods. Third, commonly the MSME business is not supported by loan funds from banks, but from their own funds.

The role of MSME actors in the midst of the outbreak to maintain the growth of MSMEs is very important. Currently, what the government needs to do is to contain the spread of Covid-19. Because, holding back the spread of Covid-19 will affect the economy.

\section{RESEARCH METHODOLOGY}

The research method used by the writer is descriptive qualitative research method. Qualitative method is a research procedure that produces descriptive data in the form of written words from people and observable behavior, supported by literature studies or literature studies based on library study experiences in the form of data and numbers so that they are realistic and well understood [5]. The data collection methods that the authors use are as follows: 1. Interview is a direct question and answer activity with parties closely related to the implementation of research, in order to obtain information on the data needed and related to research problems. 2. Literature Study Literature study is a method of collecting data by reading books, literature, journals, references related to this research and previous research related to the research being carried out. 3 . Observation

\section{DISCUSSION}

The COVID-19 pandemic currently occurring inevitably affects various sectors. At the global economic level, the COVID-19 pandemic has a very significant impact on the domestic economy of the nation-state and the 
existence of MSMEs. The Organization for Economic Co-operation and Development (OECD) report states that this pandemic has implications for the threat of a major economic crisis marked by the cessation of production activities in many countries, falling levels of public consumption, loss of consumer confidence, falling stock markets which ultimately leads to uncertainty [4]. If this continues, the OECD predicts a decline in output levels of between a fifth and a quarter in many countries, with consumer spending potentially falling by about a third.

This prediction also threatens Indonesia's national economy. Aknolt Kristian Pakpahan said there were three implications for Indonesia related to the COVID-19 pandemic, namely the tourism, trade and investment sectors. Indonesia, which is dominated by the existence of Micro, Small and Medium Enterprises (MSMEs) as the backbone of the national economy, has also been seriously affected not only in terms of total production and trade value but also on the number of workers who have lost their jobs due to this pandemic. Data from the Ministry of Cooperatives and Small and Medium Enterprises (KemenkopUKM) shows that in 2018 there were 64,194,057 MSMEs in Indonesia (or around 99 percent of the total business units) and employed 116,978,631 workers (or around 97 percent of the total workforce) work in the economic sector) [4].

The study made by the Ministry of Finance shows that the COVID-19 pandemic has negative implications for the domestic economy, such as a decrease in public consumption and purchasing power, a decline in company performance, threats to the banking and financial sectors, and the existence of MSMEs. In the aspect of public consumption and purchasing power, this pandemic has caused a large number of workers to decrease or even lose their income so that it affects the level of consumption and purchasing power of the community, especially those in the category of informal workers and daily workers. Most people are very careful about managing their financial expenses because of the uncertainty about when this pandemic will end. This has led to a decline in people's purchasing power for consumer goods and put pressure on the producer and seller sides. In the corporate aspect, this pandemic has disrupted the performance of companies, especially those engaged in the trade, transportation and tourism sectors. The social distancing policy which was later changed to physical distancing and working from or at home had an impact on the decline in company performance which was then followed by layoffs.

There are even some companies that went bankrupt and finally chose to close their businesses. In the banking and financial aspects, this pandemic has raised fears of debt or credit repayment problems which in turn have an impact on the sustainability of bank performance [6]. Many creditors have asked for loosening of the limit and amount of debt and credit installment payments from banks. In addition, entrepreneurs must pay attention to fluctuations in the rupiah exchange rate that will disrupt the production process, especially for companies that depend on imported raw materials. Moreover, this pandemic has threatened foreign investment to run off from Indonesia which of course endangers the government's strategic projects.

In the aspect of MSMEs, the existence of this pandemic has caused a decline in performance on the demand side (consumption and purchasing power of the public) which ultimately has an impact on the supply side, namely termination of employment and the threat of default on credit payments. In this pandemic situation, according to KemenkopUKM there are around 37,000 MSMEs who report that they are very seriously affected by this pandemic, marked by: around 56 percent reported a decrease in sales, 22 percent reported problems in the aspect of financing, 15 percent reported problems with the distribution of goods, and 4 percent reported difficulties in obtaining raw materials [2].

The problems above are also increasingly widespread when linked to the large-scale social restrictions (PSBB) policy which is implemented in several regions in Indonesia. Referring to the Minister of Health Regulation No. 9/2020 concerning PSBB Guidelines for the Acceleration of Handling 
COVID-19, PSBB includes restrictions on certain activities of residents in an area suspected of being infected with COVID-19 including restrictions on the movement of people and / or goods for a particular province or district / city to prevent the spread of COVID-19 [1] . These restrictions are at least carried out through school and work vacations, restrictions on religious activities, and / or restrictions on activities in public places or facilities. It is feared that with the existence of PSBB, economic activities, especially production, distribution, and sales will experience disruption, which in turn will further contribute to the performance of MSMEs and the national economy, as the results of the study by the Ministry of Finance above. It is not wrong if there are concerns by looking at the large number of MSMEs in Indonesia and the number of workers absorbed in MSMEs. According to data from the Central Statistics Agency (BPS), the contribution of MSMEs to Indonesia's Gross Domestic Product (GDP) reached 61.41 percent in 2018. Of course this contribution shows the role of MSMEs as the backbone of Indonesia's national economy [3].

A big task rests on the shoulders of the Indonesian Government regarding the current COVID-19 pandemic: first, maintaining the safety and health of the Indonesian people as the main focus and second, maintaining the rate of economic growth. Predictions of global economic growth need to be used as input for the government in designing economic policies, especially solutions for MSMEs. A number of international institutions have released their predictions for global economic growth in 2020, such as JP Morgan, which states that global economic growth will be minus 1.1 percent and the International Monetary Fund (IMF) which even predicts global economic growth will be minus 3 percent. Meanwhile for Indonesia's economic growth, the IMF predicts that Indonesia will still experience positive economic growth of 0.5 percent from the initial target of 5 percent in 2020, while Finance Minister Sri Mulyani predicts Indonesia's economic growth will be in the range of 0.3-2.8 percent in 2020.10 This figure, both the number of MSMEs and their contribution as well as the prediction of global and Indonesian economic growth, needs to get serious attention and be used as material for government evaluations to design policies and strategies that are right for the existence of MSMEs in Indonesia. What can be done? The COVID-19 pandemic situation provides challenges as well as opportunities for the government to maintain the existence of MSMEs.

This means that there needs to be a short-term solution to help MSMEs and workers who are members of it. Opportunity means that short-term solutions need to be followed by long-term solutions, especially when it is related to the industrial era 4.0 which requires the availability of digital technology to support economic activity. There are several short-term solutions to maintain the existence of MSMEs. According to the OECD, several solutions need to be considered, namely: strict health protocols in carrying out economic activities by MSMEs, delaying debt or credit payments to maintain MSME financial liquidity, financial assistance for MSMEs, and structural policies.

First, strict health protocols can be applied when the government gives permission for MSMEs to carry out their activities. The obligation to use masks, gloves, and a safe distance between workers can be a requirement for MSMEs to continue carrying out their activities. Of course there needs to be cooperation from MSME actors and tight supervision from the competent agencies so that this health protocol can run well. In this context, the government can involve civil servants at the village office in collaboration with the village supervisors (Babinsa / TNI) and community security and order guards (Babinkamtibmas / police) in monitoring the implementation of health protocols for MSMEs who are allowed to carry out their activities.

Second, the government can issue a policy to provide leniency in the payment of debt or credit installments for MSMEs or even postpone the payment process for the next six months by considering the financial liquidity of MSMEs. This includes simplifying the administrative process for obtaining a loan in the midst of this 
emergency situation. This can be done so that MSME actors, including workers, can maintain the level of consumption and purchasing power as well as support the running of the national economy. Third, government provides financial assistance to MSME players. The Indonesian government has disbursed a budget of 70.1 trillion Rupiahs for tax incentives and stimulus for people's business credit from the total budget of 405.1 trillion rupiahs overcoming the Covid-19 pandemic through the 2020 State Budget.

The distribution of the budget must be transparent, clear, and on target so that the existence of MSMEs and real economic activities is maintained. In addition to the predetermined budget, the government can also encourage the banking sector, both stateowned and private banks, to be able to provide soft loans to MSME players, of course with strict mechanisms that are entitled to loans with this soft interest rate. Do not let this loan be misused and ultimately harm the performance of the lending bank. Regarding assistance to MSMEs, two government agencies that deal directly with MSMEs, namely the Ministry of Cooperatives and Small and Medium Enterprises (KemenkopUKM) and the Ministry of Industry (Kemenperin) have designed several strategies to assist MSMEs. KemenkopUKM has provided at least three stimuli for MSMEs during this pandemic to maintain the sustainability of MSME activities, namely: leniency in loan payments, six months of MSME tax relief, and cash transfers for micro-scale businesses.

Meanwhile, the Ministry of Industry plans to: provide loans at low interest rates (lower than the interest rate for micro enterprises) to small and medium enterprises (SMEs), link SMEs with online technology shops to help with the marketing and sales of SME products such as Tokopedia, Shopee, and Blibli, collaborating with local industries that provide raw materials for SME production needs, and collaborating with the Ministry of Foreign Affairs and Industrial Attaches abroad to carry out the trade negotiation process to continue export activities of the products produced by Indonesian SMEs.

Fourth, structural policies for the long term interest. This policy is not only used to deal with the COVID-19 pandemic but also the Industrial 4.0 era in the future. This policy includes short-term policies for MSMEs, namely the introduction of digital technology and training for MSME actors and workers as well as long policies for MSMEs to adapt to the use of technology for production processes, use of digital technology media to promote MSME products, and find potential markets for the resulting product.

In the short term, there needs to be assistance for MSME players to be able to take advantage of e-commerce media (online shopping) to sell their products. Data from the Central Statistics Agency shows that in 2018 only 3.79 million MSMEs (or around 8\%) used online platforms to market their products [2]. Of course a situation like this can be a way out to increase the number of MSMEs utilizing the online platform.

Then, the short-term policies were followed by long-term policies. The government can start by making a road map for the development of MSMEs in facing the Industrial era 4.0 starting from retraining (retraining) of MSME workers to adapt to the use of new production technology and digital technology, development of telecommunications infrastructure and internet programs into villages, involving academia and big business. In assisting the introduction and use of production technology and digital media, as well as reviving the partnership program for large businesses and MSMEs.

This structural policy was carried out to support the strengthening of MSMEs while at the same time supporting the development of MSMEs in the Industrial 4.0 era. Another way that can be done to help MSMEs survive this pandemic situation is to utilize Social and Environmental Responsibility (TJSL) funds owned by private companies and state-owned enterprises (BUMN). The government needs to issue instructions and guidelines for all BUMNs to divert existing TJSL funds to directly help MSMEs affected by the COVID19 pandemic. BUMN can also involve 
MSMEs in the production process of products that can be filled by UMKM workers. For example, state-owned enterprises engaged in the production of pharmaceuticals and personal protective equipment (PPE) such as masks and medical clothing could involve MSME workers engaged in clothing production to produce large-scale PPE needs.

Seeing the market potential regarding the need for PPE for both domestic and international needs, this opportunity can be taken advantage of while at the same time providing a sense of security for the threat of termination of employment or production closure experienced by MSMEs in the short term. For private companies, TJSL funds can also be diverted to help MSMEs around the company. The form of assistance can be in the form of direct assistance, such as providing basic food packages or purchasing UMKM products to be distributed to other places. Actions like this, at least in the short term, can provide a sense of security for MSME actors.

\section{CONCLUSSION}

No country can predict when the COVID-19 pandemic will end. A simple way to adapt and deal with this pandemic is to prepare short-term and long-term strategies while continuing to hope that a vaccine for the COVID-19 virus will soon be discovered and mass produced. The short-term policy that can be implemented is financial assistance in the form of soft loans or direct cash assistance by involving the government and the private sector. Meanwhile, the longterm strategy is focused on the introduction and use of digital technology for MSMEs as well as preparation for entering the Industrial 4.0 era.

\section{REFERENCES}

[1] Abrar, Thea Fatanah. "Don't be surprised, this is Sri Mulyani's prediction about the Indonesian economy." CNBC Indonesia. accessed April 22, 2020. https://www.cnbcindonesia.com/market / 20200419092613-17-152924 / don't be surprised-this-sri-mulyani-

questionekonomi-ri-prediction.

[2] Bhwana, Petir Garda, "Ministry Proposes Soft Loans for SMEs Affected by COVID19." Tempo.co. Accessed 22 April 2020. https://en.tempo.co/read/1327970/minis try-proposes-soft-loans-forsmesaffected-by-covid-19.

[3] Judge, Rakhmat Nur. "Jokowi Poured Rp. 405.1 Trillion to Overcome Covid19, Here Are the Details." Compass. Accessed $22 \quad$ April 2020. https://nasional.kompas.com/read/2020/ 03/31/18253871 / jokowi-gelontorkanrp 4051-trillion-to-overcome-covid-19in details.

[4] Ministry of Cooperatives and Small and Medium Enterprises. "Data Development for Micro, Small, Medium Enterprises (UMKM) and Large Enterprises (UB) in 2017-2018.

[5] Gunawan, I. (2017). Qualitative Research Methods. In Bumi Aksara (5th ed.).

[6] Pakpahan, A. K. (2020). COVID-19 and its Implications for Micro, Small and Medium Enterprises. 20 (April).

[7] Suci, Fellyanda. 2020. Complete Story of the Origin of the Corona Virus in Wuhan 